\title{
PEMAHAMAN ASPEK-ASPEK DALAM HAKIKAT SAINS (NATURE OF SCIENCE) OLEH GURU SEKOLAH DASAR DI WILAYAH 4P (PEDALAMAN, PERBATASAN, PERKOTAAN, DAN PESISIR)
}

\author{
Muhsinah Annisa ${ }^{1}{ }^{*}$, Listiani $^{2}$ \\ 1 Jurusan Pendidikan Guru Sekolah Dasar Universitas Borneo Tarakan \\ 2 Jurusan Pendidikan Biologi Universitas Borneo Tarakan
}

\begin{abstract}
Abstrak
Nature of Science knowledge understanding can be related to natural science conceptual understanding. It is expected that having understanding in nature of science concepts will minimize misconception in science concepts. Therefore, every teacher should understand aspects on nature of science. Because of the importance of nature of science, a research on elementary school teachers' understanding on nature of science in 4P areas (rural, bordered, coastal, and urban) should be done. This research is aimed to to know the use of View of Nature of Science form B that has been translated and adapted to Bahasa Indonesia. This is qualitative research, in which focusing on evaluating elementary school teachers' view of nature of science and the use of transadapted VNOS form B questionnaire that has been developed by Lederman and El-Khalick in the USA. Indeed, there are six aspect of Nature of Science that has been measured using VNOS form B. The result shows that most of respondents are naïve in understanding those six NOS aspects.
\end{abstract}

\author{
Keywords: \\ Aspects of Nature of \\ Science, Elementary \\ School Teachers, Science \\ Education
}

\section{Pendahuluan}

Kehidupan masyarakat modern tidak bisa terlepas dari 'budaya' sains dan teknologi. Miller (Yuenyong \& Narjaikaew, 2009) menuturkan kehidupan sehari-hari masyarakat secara signifikan dipengaruhi oleh ilmu pengetahuan salah satunya ditunjukkan dengan semakin cepat peningkatan jumlah produk sains dan teknologi yang erat dengan keseharian masyarakat. Adapun kemampuan yang berhubungan dengan penggunaan ilmu pengetahuan dan teknologi dimunculkan dengan istilah literasi sains. Literasi sains (scientific literacy) merupakan salah satu ranah studi PISA. Menurut Rustaman (Sains Edutainment, 2012) dalam konteks PISA, literasi sains didefinisikan sebagai kapasitas untuk menggunakan pengetahuan dan kemampuan ilmiah, mengidentifikasi pertanyaan-pertanyaan dan menarik kesimpulan berdasarkan bukti-bukti dan data-data yang ada agar dapat memahami dan membantu peneliti untuk membuat keputusan tentang dunia alami dan interaksi manusia dengan alamnya.

Literasi sains (Scientific literacy) akhir-akhir ini sedang menjadi pusat perhatian dan penelitian di dunia pendidikan. Penelitian tentang literasi sains ini pun menitikberatkan pada pemahaman hakikat sains (Nature of Science). Pemahaman tentang hakikat sains ini bertujuan untuk menciptakan masyarakat yang cerdas sebagai pengguna informasi ilmiah dan masyarakat yang efektif dalam tingkat lokal dan global (Smith \& Scharman, 1998). Penguasaan literasi sains diharapkan dapat mempermudah siswa untuk beradaptasi dengan kemajuan ilmu pengetahuan dan teknologi di masa mendatang ( Nurfaidah, 2017).

Pemahaman tentang hakikat sains berhubungan dengan kemampuan masyarakat dalam memahami sains secara menyeluruh dan mampu mengaplikasikannya dalam sehari-hari. Dengan memahami hakikat sains, seseorang diharapkan dapat berfikir secara ilmiah dan bijaksana dalam menyikapi setiap permasalahan. Hakikat sains adalah landasan untuk berpijak dalam mempelajari IPA (Tursinawati, 2016). 
Hal tersebut penting karena dengan perkembangan ilmu pengetahuan dan teknologi, manusia dituntut untuk lebih bijaksana dan berhati-hati dalam menggunakannya. Manusia juga harus memiliki sifat terbuka dan rasa ingin tahu yang tinggi supaya dapat mengikuti pesatnya perkembangan ilmu pengetahuan. Untuk mempersiapkan generasi yang siap mengikuti perkembangan zaman maka perlu dipersiapkan sejak dini, yaitu sejak berada pada tingkat pendidikan dasar. Oleh karena itu, sekolah dasar sebagai salah satu institusi formal seyogyanya memiliki tenaga pendidik yang mumpuni dalam mempersiapkan peserta didik menghadapi perkembangan yang ada.

Untuk dapat mengikuti perkembangan, salah satu hal yang harus dicapai adalah masyarakat yang berliterasi dan memahami hakikat ilmu pengetahuan alam. Sains berupaya untuk membangkitkan minat dan rasa ingin tahu manusia agar kecerdasan dan pemahaman tentang alam seisinya terus berkembang. Diiringi dengan mengalirnya informasi, jangkaun sains semakin luas dan lahirlah sains terapan, yakni teknologi. Sains dan teknologi yang dicapai oleh suatu bangsa biasanya digunakan sebagai tolok ukur untuk kemajuan suatu bangsa. Kemajuan bangsa ini sangat ditentukan oleh kemampuan sumber daya manusia Indonesia dalam penguasaan ilmu pengetahuan dan teknologi ( Desstya, 2014). Sayangnya di Indonesia belum banyak dilakukan penelitian tentang pemahaman hakikat ilmu pengetahuan baik untuk pengajar, calon guru, maupun siswa, khususnya di kota Tarakan.

Tarakan merupakan sebuah kota yang termasuk dalam wilayah perbatasan sehingga penting untuk menyiapkan peserta didiknya untuk berperan serta dalam persaingan nasional maupun internasional. Mengingat pentingnya memahami hakikat ilmu pengetahuan alam, maka para pengajar di tingkat sekolah dasar diharapkan memiliki kemampuan tersebut supaya dapat menghasilkan lulusan yang memahami hakikat sains. Untuk mengetahui kemampuan tersebut maka dilaksanakan penelitian terhadap guru guru di sekolah dasar di kota Tarakan tentang pemahaman hakikat sains mereka.

Untuk dapat mengetahui pemahaman hakikat sains maka diperlukan instrument. Salah satu instrument yang dapat digunakan adalah VNOS (View of Nature of Science) yang diterjemahkan dan diadaptasi dari versi aslinya yang dikembangkan oleh Lederman dan Abd-El-Khalick di Amerika. VNOS ini merupakan instrumen kuisioner dengan pertanyaan terbuka. Data dari kuisioner kemudian menunjukkan pemahaman tentang aspek-aspek hakikat sains.

\section{Metode Penelitian}

Penelitian ini adalah penelitian deskriptif kualitatif dimana data yang diperoleh kemudian digunakan untuk mendeskripsikan pemahaman guru - guru sekolah dasar terhadap aspek-aspek dalam hakikat sains. Sampel penelitian ini adalah guru-guru sekolah dasar di daerah pedalaman (Long Peso), Perbatasan (Sebatik), Perkotaan (Tarakan), dan Pesisir (Derawan). Sebanyak lima sekolah dari setiap daerah dipilih sebagai sampel dengan menggunakan teknik purposive sampling, yaitu dengan mempertimbangkan tingkat kualitas sekolah (Baik, sedang, dan cukup). Pada setiap sekolah, dipilih 3 guru matapelajaran IPA sebagai responden yang akan diberi instrumen NOS. Instumen yang digunakan dalam penelitian diadaptasi dari instrumen VNOS form B. Proses penerjemahan dan adaptasi instrument dilakukan oleh peneliti dengan megadaptasi proses penerjemahan yang telah dilakukan oleh Montoya et al. (2011). Proses adaptasi dan penerjemahan ke dalam bahasa Indonesia dilakukan dengan mempertimbangkan kesesuaian konten dengan bahasa dan budaya Indonesia.

Jawaban dari kuisioner kemudian dianalisis. Analisis dilakukan dengan mencocokkan jawaban dengan deskripsi yang dikemukakan oleh Lederman (2002), yaitu terdiri dari responden yang belum memahami aspek-aspek dalam hakikat sains, responden yang sedikit memahami dan responden yang memahami karakter hakikat sains. Kategori tersebut dibagi berdasarkan enam aspek dalam hakikat sains.

\section{Hasil Dan Pembahasan}

\section{Penerjemahan dan Adaptasi VNOS form B}

Hasil penelitian menunjukkan bahwa View of Nature of Science form B merupakan Instrumen yang dapat digunakan untuk mengukur pemahaman hakikat sains. VNOS form B diadaptasi ke dalam bahasa Indonesia dan disesuaikan dengan budaya dan bahasa Indonesia supaya dapat digunakan di Indonesia. Proses adaptasi dan penerjemahan VNOS form B mengikuti alur Montoya dkk. (2011). Dalam proses adaptasi dan penerjemahan, hal yang perlu diperhatikan adalah kemudahan kalimat dan bahasa yang digunakan sehingga tidak membingungkan responden. VNOS form $B$ ini dalam proses penerjemahannya telah diujicobakan pada sekelompok mahasiswa calon guru IPA/Biologi. Hasilnya menunjukkan bahwa VNOS form B layak digunakan untuk mengetahui pemahaman hakikat sains guru maupun calon guru di Indonesia (Listiani dan Kusuma, 2017) 
VNOS form B yang digunakan dalam penelitian ini terdiri dari 6 soal yang mewakili setiap aspek dalam hakikat sains. Aspek pertama yang ditanyakan pada instrumen VNOS form B ini adalah pemahaman tentang tentativeness yaitu pengetahuan tentang apakah ilmu pengetahuan bersifat mutlak atau tidak. Pertanyaan ke dua berhubungan dengan pemahaman tentang bagaimana pengaruh kreatifitas dalam proses mendapatkan ilmu pengetahuan. Aspek ke tiga berhubungan dengan pengetahuan tentang teori dan hukum. Pada pertanyan ini, responden diminta untuk mendefinisikan teori dan hukum. Pertanyaan ke empat merupakan pertanyaan yang berhubungan dengan adanya hubungan antara kodisi sosial budaya masyarakat dalam pencarian ilmu pengetahuan. Aspek NOS ke empat dituangkan dalam pertanyaan tentang persamaan dan perbedaan antara sains dan seni. Pertanyaan selanjutnya adalah mengenai aspek empirical base yang dituangkan dalam pertanyaan berupa penerapan metode saintifik. Responden diminta untuk menjelaskan tentang pentingnya penggunaan metode saintifik dalam menemukan ilmu pengetahuan. Aspek terakhir yang menjadi bagian dari pertanyaan dalam VNOS form B adalah aspek observasi dan inferensi dalam pencarian pengetahuan. Responden diminta untuk menjelaskan bagaimana para ilmuan dalam memutuskan suatu penemuan dan mengapa terdapat perbedaan antara satu ilmuan dengan ilmuan yang lain walaupun mereka meneliti obyek yang sama.

Semua pertanyaan pada terjemahan VNOS form B telah disesuaikan redaksi kalimatnya ke dalam bahasa Indonesia dan disesuaikan dengan kaidah EYD supaya memudahkan para responden memahami maksud di setiap pertanyaan. Selain itu, terdapat beberapa soal yang mengalami penyesuaian contoh. Artinya, pada soal aslinya, contoh kasus yang diberikan adalah kasus yang terlalu rumit untuk dipecahkan oleh seorang guru sekolah dasar, maka soal tersebut diganti dengan soal sejenis namun tetap dengan mempertimbangkan kesesuaian maksud dan tujuan soal.

Pemahaman Aspek-Aspek dalam Hakikat Sains oleh Guru Sekolah Dasar

Penelitian tentang pemahaman hakikat sains ini dilaksanakan di wilayah $4 \mathrm{P}$. Wilayah $4 \mathrm{P}$ tersebut terdiri atas wilayah pedalaman, perbatasan, pesisir, dan perkotaan yang terdapat di Kalimantan Utara. Wilayah pedalaman diwakili oleh guru-guru sekolah dasar di daerah Long Peso, wilayah perbatasan diwakili oleh guru-guru sekolah dasar di daerah Sebatik, sedangkan wilayah pesisir diwakili oleh guruguru di daerah pulau Derawan, sedangkan wilayah perkotaan diwakili oleh guru-guru di daerah kota Tarakan. Masing-masing guru yang diminta menjadi responden kemudian diberi kuesioner VNOS form B untuk mengetahui pemahaman tentang hakikat sains.

Hasil penelitian menunjukkan bahwa dari keenam aspek hakikat sains yang diukur dengan menggunakan VNOS form B, lima aspek memiliki responden yang belum memahami sama sekali tentang aspek tersebut. Kelima aspek tersebut adalah aspek kreativitas, pemahaman tentang teori dan hukum, aspek pengaruh sosial dan budaya, aspek empiris, dan aspek observasi dan inferensi dalam ilmu pengetahuan. Sedangkan pada aspek tentativeness, lebih banyak responden yang sedikit memiliki pengetahuan tersebut (Gambar 1).

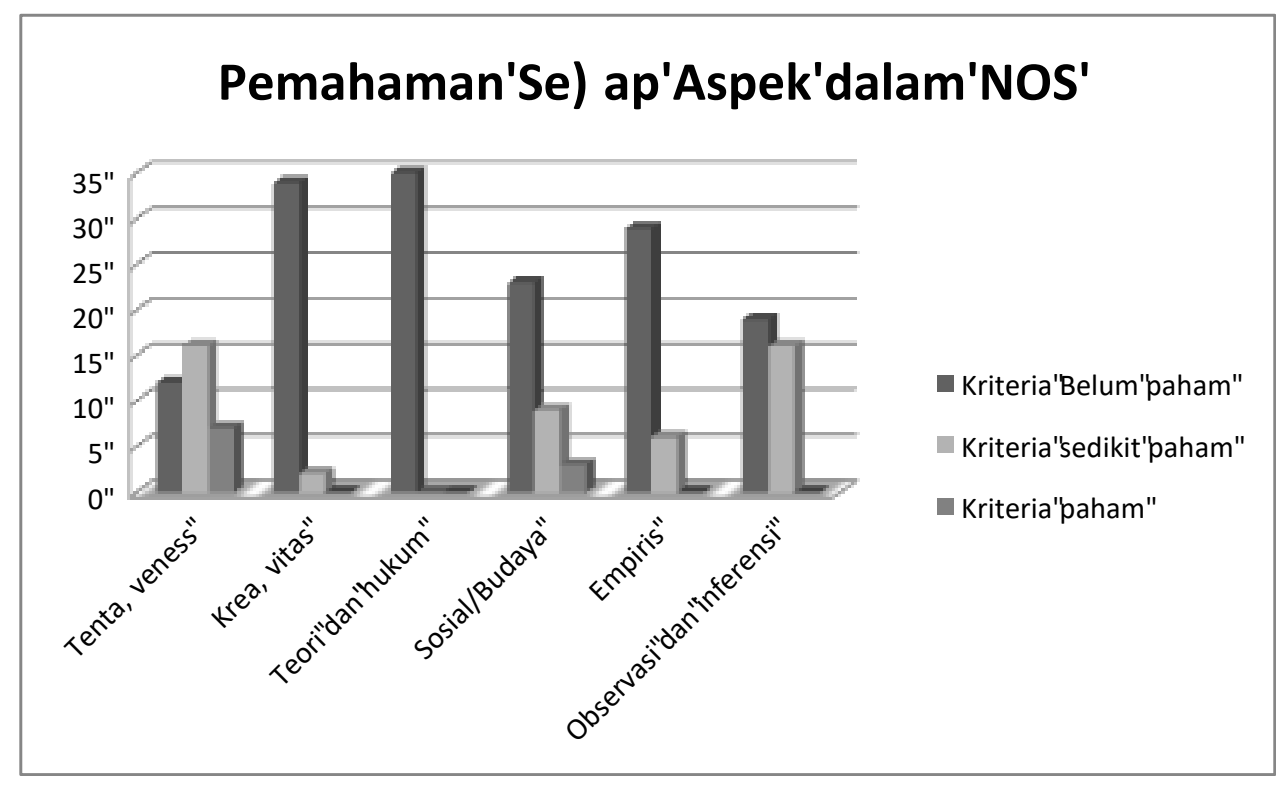

Gambar 1. Pemahaman aspek-aspek hakikat sains oleh guru sekolah dasar wilayah 4P 
Secara garis besar, Lederman (2007) telah mengidentifikasi bahwa terdapat tujuh aspek atau topik yang terintegrasi dalam hakikat sains.

Aspek yang pertama adalah tentativeness. Hal ini berarti bahwa ilmu pengetahuan alam bersifat tentative, yang berarti bahwa ilmu pengetahuan tidak kekal dan memungkinkan untuk berubah (Nielsen, 2012). Dalam penelitian ini, sebagian besar responden memiliki pemikiran bahwa ilmu pengetahuan bersifat tentative, artinya mereka meyakini bahwa suatu saat ilmu pengetahuan dapat berubah.

Selanjutnya, dalam ilmu pengetahuan terdapat aspek kreativitas dan inovasi. Artinya, dalam menemukan pengetahuan diperlukan adanya kreativitas dan inovasi. Para ilmuan menggunakan kreativitas dan inovasi-inovasi untuk menemukan hal baru (Nielsen, 2012). Sayangnya, responden dalam penelitian ini tidak mengetahui bahwa dalam menemukan pengetahuan dibutuhkan kreativitas dan inovasi.

Aspek ke tiga adalah perbedaan antara hukum dan teori. Pada aspek ini menekankan pada pemahaman tentang definisi teori dan hukum. Teori dan hukum merupakan dua hal yang memiliki kajian tentang alam semesta dari sisi yang berbeda. Artinya, antara hukum dan teori tidak ada keterkaitan sama sekali (Nielsen, 2012). Hal yang sering terjadi adalah adanya miskonsepsi bahwa terdapat hubungan antara teori dan hukum (Schwartz, 2007) dimana terdapat hierarki atau tingkatan antara teori dan hukum. Demikian juga pada penelitian ini. Hamper semua responden tidak mengetahui definisi teori dan hukum serta menyebutkan bahwa teori yang telah melalui pengujian berulang akan menjadi suatu hukum.

Aspek selanjutnya adalah pengaruh sosial dan budaya dalam ilmu pengetahuan. Tidak dapat dipungkiri bahwa ilmu pengetahuan alam dan ilmuan merupakan bagian dari masyarakat dan pasti dipengaruhi oleh kondisi masyarakat dan kebudayaan masyarakat setempat (Nielsen, 2012). Namun, responden banyak yang belum mengetahui bahwa masyarakat dan kebudayaan memiliki pengaruh terhadap ilmu pengetahuan.

Aspek ke lima adalah pengalaman empiris. Artinya ilmu pengetahuan tidak tiba-tiba saja muncul tetapi melalui serangkaian proses yang didasarkan pada pengamatan terhadap alam semesta (Nielsen, 2012). Sayangnya, responden tidak dapat menjelaskan tentang bagaimana proses penemuan ilmu pengetahuan sehingga masih banyak yang belum mengetahui bahwa dalam ilmu pengetahuan perlu adanya aspek empiris atau pengamatan terhadap fenomena alam semesta.

Aspek terakhir yang dapat diamati dengan menggunakan VNOS form B adalah aspek perbedaan antara observasi dan inferensi dalam ilmu pengetahuan. Observasi merupakan pernyataan deskriptif tentang alam semesta yang secara langsung dapat diamati dengan menggunakan panca indera, sementara inferensi merupakan hasil interpretasi seseorang atas fenomena alam yang tidak dapat dijangkau secara langsung oleh panca indera (Nielsen, 2012). Tidak dapat dipungkiri bahwa dalam ilmu pengetahuan selalu ada observasi dan interpretasi oleh para ilmuan. Salah satu faktor yang mempengaruhi hasil observasi dan interpretasi ini adalah pengetahuan yang dimiliki oleh masing-masing orang. Pada aspek ini, jumlah responden yang paham dan yang sedikit paham tidak jauh berbeda, walaupun masih lebih banyak responden yang belum memahami aspek observasi dan inferensi. Hal ini menunjukkan bahwa sebagian responden sudah mengetahui bahwa dalam menemukan ilmu pengetahuan diperlukan adanya observasi dan interpretasi data dan dalam proses penginterpretasian data dipengaruhi oleh pengetahuan masingmasing ilmuan.

Aspek-aspek tersebut penting untuk diketahui untuk mencegah terjadinya miskonsepsi terhadap konsep-konsep ilmu pengetahuan. Selama ini ilmu pengetahuan diajarkan dengan cara mengahafal konsep-konsep yang sudah jadi. Hal tersebut rentan menimbulkan miskonsepsi.

\section{VNOS Form B untuk Mengetahui Pemahaman Hakikat Sains Guru Sekolah Dasar}

Terbatasnya informasi dan referensi yang berkaitan tentang pemahaman hakikat sains baik pada guru, siswa, maupun mahasiswa di Indonesia merupakan salah satu parameter yang menunjukkan bahwa masih minimnya penelitian yang berhubungan dengan pemahaman hakikat sains. Hal tersebut kemudian menyebabkan tidak tersedianya instrumen untuk asesmen pengetahuan hakikat sains dalam bahasa Indonesia. Pada dasarnya, sudah banyak peneliti di luar Indonesia yang melakukan penelitian tentang pengetahuan hakikat sains dan merancang instrumen untuk mengukur pemahaman hakikat sains, namun instrumen tersebut masih belum berbahasa Indonesia. Salah satu instrumen yang dapat digunakan untuk mengetahui pemahaman hakikat sains adalah instrumen yang bernama VNOS (View of Nature of Science).

VNOS merupakan instrumen yang dikembangkan oleh Lederman, Abd-El-Khalick, Bell, dan Schwartz (2002) yang telah teruji validitas dan reliabilitasnya. Di Amerika Serikat, VNOS merupakan instrumen yang telah digunakan secara luas untuk mengetahui pemahaman dan pengetahuan tentang hakikat sains. Lederman dkk. (2002) telah melakukan penelitian mengenai instrumen VNOS serta melakukan revisi terhadap VNOS tersebut. Terdapat tiga bentuk instrumen VNOS, yaitu VNOS form A, 
VNOS form B, VNOS form C, dan VNOS form D. dari ketiga bentuk instrumen tersebut, VNOS form B merupakan instrumen yang paling sesuai untuk mengukur pemahaman hakikat sains guru dan calon guru (Listiani dan Kusuma, 2017).

Selanjutnya, Lederman dkk. (2002) juga menyatakan bahwa asesmen terhadap pengetahuan hakikat sains sangat penting. Asesmen dapat dilakukan mulai dari tingkat pendidikan yang paling rendah sampai dengan pendidikan yang tinggi. Lederman dkk. (2002) juga menemukan bahwa pemahaman hakikat sains siswa mulai dari tingkat pendidikan dasar sampai dengan pendidikan menengah masih sangat kurang. Oleh karena itu perlu dilakukan penelitian yang intensif untuk terus memantau perkembangan pengetahuan hakikat sains dan melakukan upaya-upaya untuk melakukan peningkatan pemahaman hakikat sains. Dengan menggunakan instrumen VNOS form B diharapkan dapat memberikan gambaran tentang pemahaman hakikat sains guru-guru di Indonesia, terutama guru sekolah dasar. Mengingat pentingnya pemahaman hakikat sains dan perlu diajarkan sejak dini, maka pengajar di tingkat pendidikan dasar juga harus memiliki pemahaman hakikat sains supaya dapat mengajarkan hakikat sains pada peserta didik.

\section{Simpulan dan Saran}

Ilmu pengetahuan memiliki beberapa aspek yang perlu untuk dipahami supaya tidak terjadi miskonsepsi dalam mempelajari sains atau ilmu pengetahuan alam. Enam dari tujuh aspek hakikat sains yang diteliti oleh Lederman, dapat diteliti dengan menggunakan sebuah instrument yang disebut dengan VNOS form B. instrument ini dapat digunakan untuk menemukan informasi tentang pengetahuan dan pemahaman aspek-aspek dalam hakikat sains. Enam aspek tersebut adalah tentative dalam ilmu pengetahuan, kreatifitas, perbedaan antara teori dan hukum, pengaruh sosial dan budaya, empiris dan observasi, serta perbedaan antara observasi dan inferensi.

Hasil penelitian menunjukkan bahwa sebagian besar responden tidak memiliki pemahaman tentang aspek-aspek tersebut, lima dari enam aspek yang diteliti didominasi oleh responden yang tidak memiliki pengetahuan tentang aspek-aspek tersebut sama sekali.

\section{Daftar Pustaka}

Abd-El-Khalick dan Lederman, N.G. (2000). Improving Science Teachers' Conceptions of Nature of Science: A Critical Review of the Literature. International Journal of Science Education. Vol 22. No. 7. 665701

Akerson, V.L., Buck, G.A., Donnelly, L.A., Nargund-Joshi, V., dan Weiland, I. S. (2011). The Importance of Teaching and Learning Nature of Science in the Early Chilhool Years. Journal of Science Education and Technology. Vol. 20.537-549

Dessty, Anatri. 2014. Kedudukan Dan Aplikasi Pendidikan Sains Di Sekolah Dasar. Profesi Pendidikan Dasar, Vol.1, No. 2.

Lederman, N.G., Abd-El-Khalick, F., Bell, R. L., and Schwartz, R. (2002). Views Nature of Science Questionnaire: Toward Valid and Meaningful Assessment of learners' Conception of Nature of Science.

Lederman N.G. (1992). Students' and Teachers' Conceptions of the Nature of Science: A Review of the Research. Journal of Research in Science Teaching. Vol. 24 no. 9. 331-359.

Lhye, T.L. and Kwen, B.H. (2004). Assessing the Nature of Science Views of Singaporean Pre-Service Teachers. Australian Journal of Teacher Education, 29, 2

McCommas, W. \& Almazroa, H. (1998). The Nature of Science in Science Education: An introduction. Science and Education. 7, 511-532.

Listiani dan Kusuma, A.E. (2017). View of Nature of Science (VNOS) Form B: Sebuah Instrumen untuk Mengetahui Pemahaman Konsep Hakikat Sains Calon Guru di Universitas Borneo Tarakan. Jurnal Pendidikan Biologi Indonesia. Vol. 3. No. 1. 45 - 54. 
Montoya, A., Llopis, N., \& Gilaberte, I. (2011). Validation of the translation of an instrument to measure reliability of written information on treatment choices: A study on attention deficit/hyperactivity disorder (ADHD). Education for Health, 24 (3). http://www.educationforhealth.net

Nielsen, H.K. (2012). Scientific Communication and the Nature of Science. Science \& Education, DOI 10.1007/s11191-012-9475-3.

Nurfaidah, Siti Sholiha. 2017. Analisis Aspek Literasi Sains Pada Buku Teks Pelajaran Ipa Kelas V SD. Mimbar Sekolah Dasar, Vol 4(1). Di akses melalui http://ejournal.upi.edu/index.php/mimbar, DOI: $10.23819 /$ mimbar-sd.v4i1.5585

Schwartz, R., Northcutt, C.K., Mesci, G. (2013, April). Science research to science teaching: Developing pre service teachers' knowledge \& pedagogy for nature of science and inquiry. Paper presented at international conference of the National Association for Research in Science Teaching. Rio Grande, Puerto Rico.

Schwartz, R. (2007). What's in a Word? Science Scope 31 no. 2.

Smith, M.U. and Scharmann, L.C (1998) Defining versus Describing the Nature of Science: A Pragmatic Analysis for Classroom Teachers and Science Educators. John Wiley and Sons, Inc.

Tursinawati. 2016. Penguasaan Konsep Hakikat Sains Dalam Pelaksanaan Percobaan Pada Pembelajaran IPA Di SDN Kota Banda Aceh. Pendidikan Guru Sekolah Dasar (PGSD) JURNAL PESONA DASAR Universitas Syiah Kuala Vol. 2 No.4, April 2016, hal 72-84 ISSN: 2337-9227

Yuenyong \& Narjaikaew. (2009). Scientific Literacy and Thailand Science Education. International Journal of Environmental \& Science Education. 4 (3), 335-349. 